\title{
Phase composition and microstructure of WC-Co alloys obtained by selective laser melting
}

\author{
Roman S. Khmyrov, Alexandr P. Shevchukov", Andrey V. Gusarov, and Tatyana V. Tarasova \\ Moscow State University of Technology "STANKIN", 1 Vadkovsky per., Moscow 127055, Russian Federation
}

Received: 21 September 2017 / Accepted: 18 December 2017

\begin{abstract}
Phase composition and microstructure of initial WC, BK8 (powder alloy 92 wt.\% WC- 8 wt.\% Co), Co powders, ball-milled powders with four different compositions (1) 25 wt.\% WC-75 wt.\% Co, (2) 30 wt.\% BK8-70 wt.\% Co, (3) 50 wt.\% WC-50 wt.\% Co, (4) 94 wt.\% WC-6 wt.\% Co, and bulk alloys obtained by selective laser melting (SLM) from as-milled powders in as-melted state and after heat treatment were investigated by scanning electron microscopy and X-ray diffraction analysis. Initial and ball-milled powders consist of WC, hexagonal $\alpha$-Co and face-centered cubic $\beta$-Co. The SLM leads to the formation of major new phases $\mathrm{W}_{3} \mathrm{Co}_{3} \mathrm{C}, \mathrm{W}_{4} \mathrm{Co}_{2} \mathrm{C}$ and face-centered cubic $\beta$-Co-based solid solution. During the heat treatment, there occurs partial decomposition of the face-centered cubic $\beta$-Co-based solid solution with the formation of $\mathrm{W}_{2} \mathrm{C}$ and hexagonal $\alpha$-Co solid solution. The microstructure of obtained bulk samples, in general, corresponds to the observed phase composition.
\end{abstract}

Keywords: Selective laser melting / additive manufacturing / WC-Co alloys / X-ray diffraction analysis / phase composition / microstructure

\section{Introduction}

Selective laser melting (SLM) is one of the additive manufacturing methods belonging to a class of actively developed and advanced technologies which serve to supplement traditional manufacturing [1,2]. As well as other methods of the additive manufacturing [3] SLM can involve the use of a wide range of metallic materials and produce parts for aerospace and medical applications [4]. A high cooling rate typical of this process often ensures obtaining materials with submicron and nanocrystalline grain structure, having increased strength and wear resistance $[5,6]$. In fact, SLM is not limited by geometric form complexity and refractoriness of material [7]. One of the examples of work with refractory materials by the SLM method is the obtaining of WC-Co bulk alloys $[8,9]$. WCCo alloys are widely used in industry as cutting tools $[10,11]$ including tools with multilayer coatings [12,13], and also can be used as wear-resistant bulk materials [14], wearresistant [15] and anticorrosion coatings [16].

Preliminary processing and composition of initial materials influence on the quality and properties of the WC-Co alloys obtained by SLM. Using of pre-sintering [8] and mechanical alloying [17] of initial WC-Co powders allows improving the density and surface finish of

\footnotetext{
* e-mail: a.shevchukov@gmail.com
}

synthesized layers. In works $[18,19]$ influence of WC/Co ratio on the cracking of bulk alloys was investigated and was shown that the powder mixture with $25 \mathrm{wt} . \% \mathrm{WC}$ and 75 wt.\% of Co can be used for SLM to obtain materials without cracks. Another important characteristic which influences on material properties during the manufacturing WC-Co alloys is phase composition. When the alloys are obtained by sintering or SLM, phases increasing fragility and decreasing fracture resistance of the material can be formed $[20,21]$. Main stable phases in $\mathrm{W}-\mathrm{Co}-\mathrm{C}$ system are $\mathrm{WC}$ and $\mathrm{W}_{2} \mathrm{C}$ double carbides, $\mathrm{WCo}_{3}$ and $\mathrm{W}_{6} \mathrm{Co}_{7}$ double intermetallic compounds, and $\mathrm{W}_{3} \mathrm{Co}_{3} \mathrm{C}, \mathrm{W}_{4} \mathrm{Co}_{2} \mathrm{C}\left(\mathrm{Me}_{6} \mathrm{C}\right.$, $\left.\mathrm{W}_{4-x} \mathrm{Co}_{2+x} \mathrm{C}, 0<x<1\right)$ and $\mathrm{W}_{6} \mathrm{Co}_{6} \mathrm{C}\left(\mathrm{Me}_{12} \mathrm{C}\right)$ n-type ternary carbides. Cobalt exists in two modifications: $\alpha-\mathrm{Co}$ (hexagonal, space group P63/mmc) and $\beta-\mathrm{Co}$ (cubic, space group Fm-3m) [22,23]. In WC-Co alloys, the transformation of $\mathrm{WC}$ carbide to $\mathrm{W}_{2} \mathrm{C}, \mathrm{Me}_{6} \mathrm{C}$, and $\mathrm{Me}_{12} \mathrm{C}$ carbides occurs due to decreasing carbon quantity in the alloy $[24,25]$. In the course of obtaining WC-Co alloys, the formation of the face-centered cubic (fcc) $\beta$-Co-based supersaturated solid solution which contains a large amount of $\mathrm{W}$ and $\mathrm{C}$ is possible $[20,26]$. In work [26] alloys with high cobalt content (W and $\mathrm{C}$ from 0 to 20 at.\%, the rest is cobalt) were obtained by quenching from the liquefied state. The lattice parameter of fcc $\beta$-Co-based solid solution increased when increasing the tungsten and carbon content in alloys from $0.3585 \mathrm{~nm}$ for $\mathrm{Co}_{90} \mathrm{~W}_{5} \mathrm{C}_{5}$ to $0.3623 \mathrm{~nm}$ for $\mathrm{Co}_{80} \mathrm{~W}_{10} \mathrm{C}_{10}$ composition. The formation of 
$\mathrm{W}_{2} \mathrm{C}, \mathrm{Co}_{3} \mathrm{~W}, \mathrm{Co}_{6} \mathrm{~W}_{6} \mathrm{C}$, and $\mathrm{Co}_{3} \mathrm{~W}_{3} \mathrm{C}$ phases were observed in WC-8wt.\% Co sintered alloys obtained at different sintering temperatures $\left(800-1600^{\circ} \mathrm{C}\right)[20]$. Sintering at $1000^{\circ} \mathrm{C}$ and higher leads to the formation of the fcc solid solution $\beta-\mathrm{Co}(\mathrm{WC})$ of $\mathrm{WC}$ in fcc $\beta$-Co.

The previous works $[18,19]$ mainly considered the influences of SLM modes on the alloy microstructure formation. This work provides a detailed consideration of the phase composition changes occurring during the process of obtaining bulk WC-Co alloys by SLM and their following heat treatment. The interconnection of phase composition and microstructure of the obtained materials is shown.

\section{Experimental}

The following powders were used as initial materials: WC No.1 (average particle size $50-80 \mathrm{~nm}$ ), WC No.2 (average particle size $0.5-1 \mu \mathrm{m}$ ), BK8 alloy powder (92 wt.\% WC8 wt.\% Co) (average particle size $2-5 \mu \mathrm{m}$ ), Co No.1 (PK1U type, average particle size 1-2 $\mu \mathrm{m}$ ), Co No.2 (average particle size $50-80 \mathrm{~nm}$ ). Four powder compositions were obtained via processing in a Retch PM 100 planetary ball mill at the rotational speed of $200 \mathrm{rpm}$ for two hours: (1) 25 wt.\% WC No.1-75 wt.\% Co No.1, (2) 30 wt.\% BK870 wt.\% Co No.1, (3) 50 wt.\% WC No.1-50 wt.\% Co No.1, (4) 94 wt.\% WC No.2-6 wt.\% Co. Powder compositions processed in a ball mill were applied to the substrate as suspensions. Hard-alloy BK20 (92 wt.\% WC- 8 wt.\% Co) and steel plates were used as substrates. The liquid having been evaporated, the thickness of the applied powder layer was estimated via an optical microscope by focusing on the powder surface and the substrate surface. The difference in scale readings of the micrometer vertical screw was the thickness of the powder layer. The average thickness of the applied layer was $40 \mu \mathrm{m}$. Powder layers were scanned by a laser beam with the wavelength $\lambda=1.07 \mu \mathrm{m}$, laser spot diameter $d=100 \mu \mathrm{m}$ with various scanning step, laser radiation power was $50 \mathrm{~W}$ with the scanning speed of $100 \mathrm{~mm} / \mathrm{s}$. Bulk samples were manufactured by alternating application and melting of powder material.

Microstructure and chemical composition analysis of investigated materials were performed with the TESCAN VEGA 3 LMH scanning electron microscope equipped with an adaptor for elemental analysis by energy dispersive spectroscopy. X-ray diffraction (XRD) analysis was used to determine the phase composition of the samples. XRD patterns were obtained by PANalytical Empyrean X-ray diffractometer with $\mathrm{CoK} \alpha$ radiation. Phase composition analysis was performed by PANalytical High Score Plus software, software [27] and ICCD PDF-2 and COD databases [28].

\section{Results and discussion}

XRD patterns of initial powders are given in Figure 1. XRD patterns of powder mixtures (1)-(4) obtained in a planetary ball mill are given in Figure 2. Initial and milled powders contain WC (space group P-6m2), hexagonal $\alpha$-Co (space group $\mathrm{P} 6_{3} / \mathrm{mmc}$ ) and cubic $\beta$-Co (space group

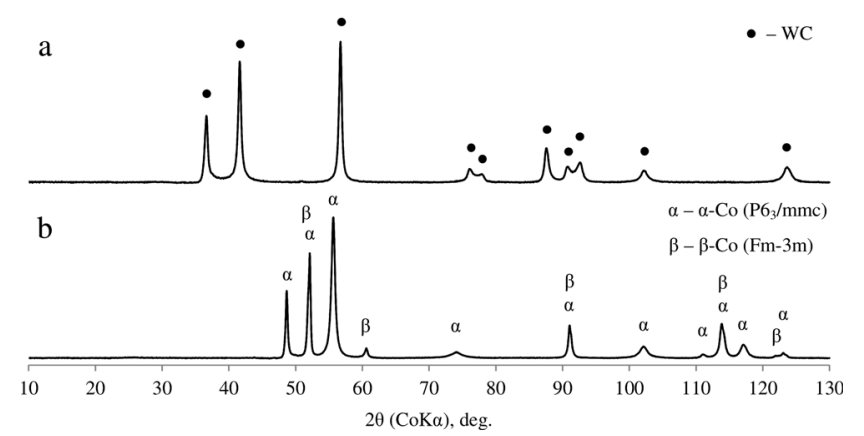

Fig. 1. XRD patterns of initial powders: $a-$ WC No.1; b - Co No.1.

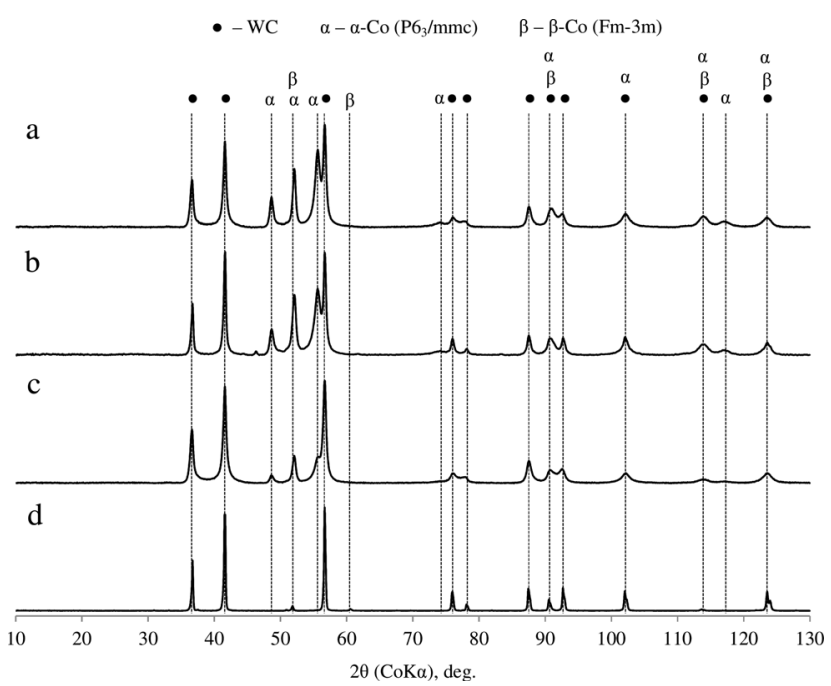

Fig. 2. XRD patterns of powder mixtures: a - (1) $25 \% \mathrm{WC}-75 \%$ $\mathrm{Co} ; \mathrm{b}-(2) 30 \%$ BK8-70\% Co; c - (3) 50\% WC-50\% Co; d - (4) $94 \%$ WC- $6 \%$ Co.

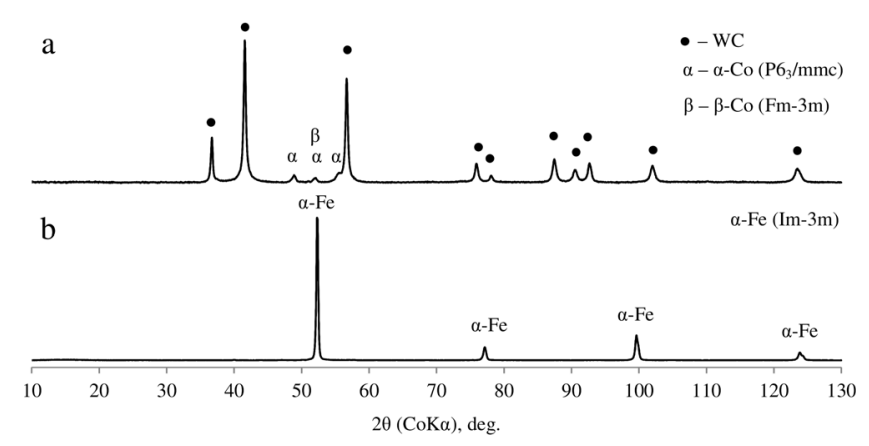

Fig. 3. XRD patterns of substrates: a - BK20; b - steel.

Fm-3m). The values of lattice parameters in the initial powders are $a=0.251 \mathrm{~nm}$ and $c=0.407 \mathrm{~nm}$ for $\alpha-C o$, and $0.354 \mathrm{~nm}$ for $\beta$-Co. To obtain bulk samples by SLM, the powders were applied to the substrates. XRD patterns of substrates (BK 20 alloy, steel) are given in Figure 3. BK20 substrate contains WC, $\alpha$-Co and $\beta$-Co phases. XRD pattern of steel contains the peaks of the only $\alpha$-Fe phase 
Table 1. Compositions of investigated materials.

\begin{tabular}{lll}
\hline Composition, wt.\% & Composition, wt.\% & Composition, at.\% \\
\hline WC & $\mathrm{W}_{93.9} \mathrm{C}_{6.1}$ & $\mathrm{~W}_{50} \mathrm{C}_{50}$ \\
BK8 $(92 \%$ WC-8\% Co) & $\mathrm{W}_{86.4} \mathrm{C}_{5.6} \mathrm{Co}_{8}$ & $\mathrm{~W}_{43.7} \mathrm{C}_{43.7} \mathrm{Co}_{12.6}$ \\
BK20 (80\% WC-20\% Co) & $\mathrm{W}_{75.1} \mathrm{C}_{4.9} \mathrm{Co}_{20.0}$ & $\mathrm{~W}_{35.3} \mathrm{C}_{35.3} \mathrm{Co}_{29.4}$ \\
(1) $25 \% \mathrm{WC}-75 \% \mathrm{Co}$ & $\mathrm{W}_{23.5} \mathrm{C}_{1.5} \mathrm{Co}_{75}$ & $\mathrm{~W}_{8.4} \mathrm{C}_{8.4} \mathrm{Co}_{83.2}$ \\
(2) $30 \% \mathrm{BK} 8-70 \% \mathrm{Co}$ & $\mathrm{W}_{25.9} \mathrm{C}_{1.7} \mathrm{Co}_{72.4}$ & $\mathrm{~W}_{9.3} \mathrm{C}_{9.3} \mathrm{Co}_{81.4}$ \\
(3) $50 \% \mathrm{WC}-50 \% \mathrm{Co}$ & $\mathrm{W}_{46.9} \mathrm{C}_{3.1} \mathrm{Co}_{50.0}$ & $\mathrm{~W}_{18.8} \mathrm{C}_{18.8} \mathrm{Co}_{62.4}$ \\
(4) $94 \% \mathrm{WC}-6 \% \mathrm{Co}$ & $\mathrm{W}_{88.2} \mathrm{C}_{5.8} \mathrm{Co}_{6.0}$ & $\mathrm{~W}_{45.2} \mathrm{C}_{45.2} \mathrm{Co}_{9.6}$ \\
\hline
\end{tabular}
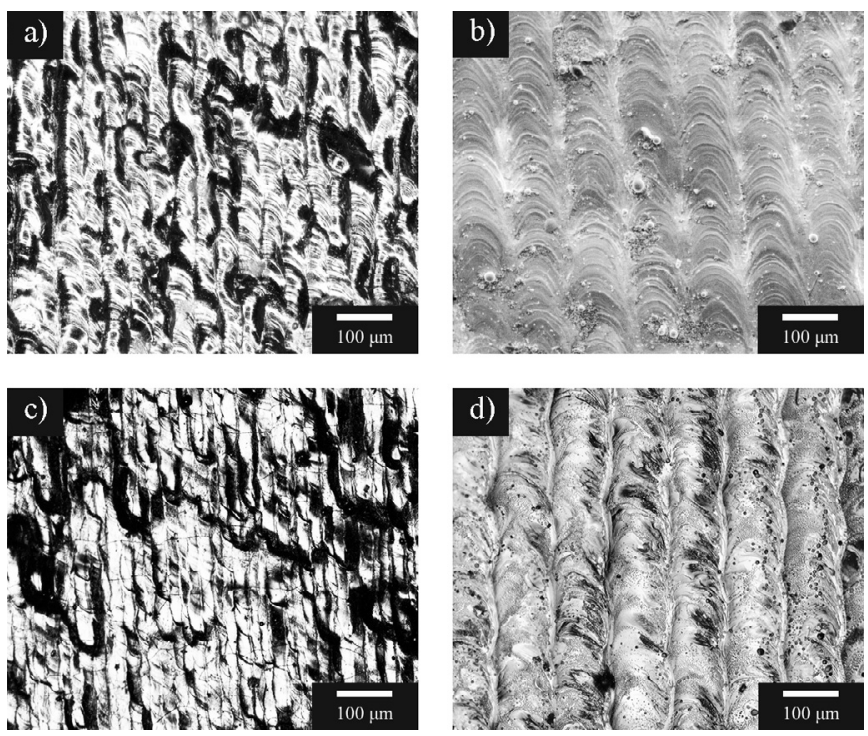

Fig. 4. The microstructure of surfaces of samples obtained by SLM: a - (1) 25\% WC-75\% Co; b - (2) 30\% BK8-70\% Co; c (3) $50 \% \mathrm{WC}-50 \% \mathrm{Co}$; - (4) $94 \% \mathrm{WC}-6 \% \mathrm{Co}$.

(space group Im-3m). Table 1 demonstrates compositions of all initial materials, substrates and studied compositions in at. $\%$ and wt. $\%$.

Microstructures of surfaces of bulk samples obtained by SLM are given in Figure 4. Scanning step for samples (1) and (3) was $50 \mu \mathrm{m}$, for samples (2) and (4) was $100 \mu \mathrm{m}$; as a result, tracks with the average width of $40-50 \mu \mathrm{m}$ (Fig. $4 \mathrm{a}$ and c) and $100 \mu \mathrm{m}$ (Fig. 4b and d) accordingly were formed.

The XRD patterns of surfaces of the samples obtained by SLM are given in Figure 5. The samples (1) and (2) are a practically single phase and contain the only phase - solid solution of tungsten and carbon in fcc $\beta$-Co marked as $\beta-\mathrm{Co}$ (W,C) (Fig. 5a and b). The formation of the solid solution is testified by extended lattice period as compared to the initial $\beta-\mathrm{Co}[26]$. $\beta-\mathrm{Co}(\mathrm{W}, \mathrm{C})$ lattice parameters in the samples (1) and (2) are 0.360 and $0.361 \mathrm{~nm}$ accordingly. XRD pattern of the sample (1) has a peak at $2 \theta=49 \mathrm{deg}$. This peak can most probably be referred to $\mathrm{W}_{4} \mathrm{Co}_{2} \mathrm{C}$ carbide phase. XRD pattern of the sample (2) contains, in addition to the peaks of the main phase, the weak peaks of which can be referred to $\mathrm{CoWO}_{4}$ oxide. WC phase has not been detected in the samples, which testifies its complete dissolution in $\beta-\mathrm{Co}$ as in the sample (2) and partial

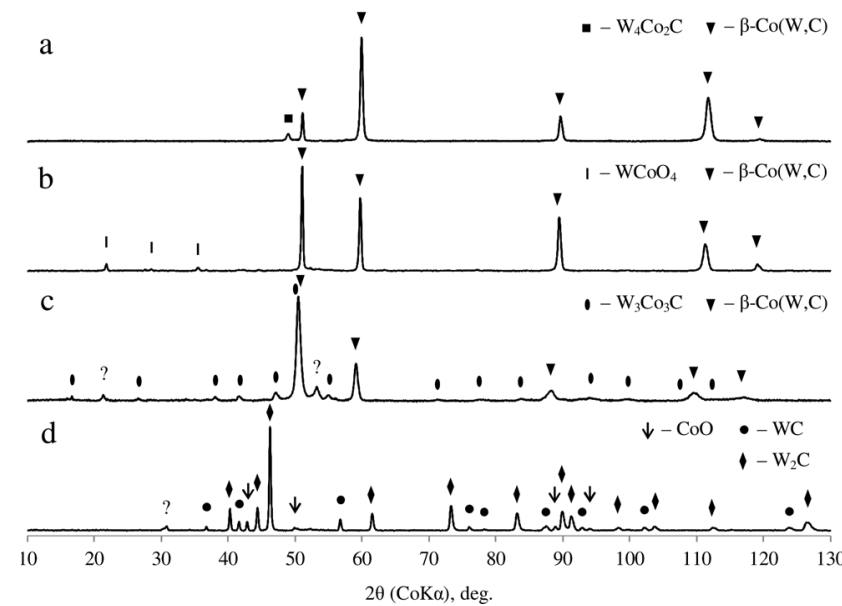

Fig. 5. XRD patterns of samples obtained by SLM: a - (1) $25 \%$ WC $-75 \%$ Co; b - (2) 30\% BK8-70\% Co; c - (3) 50\% WC-50\% Co; d - (4) $94 \%$ WC-6\% Co.

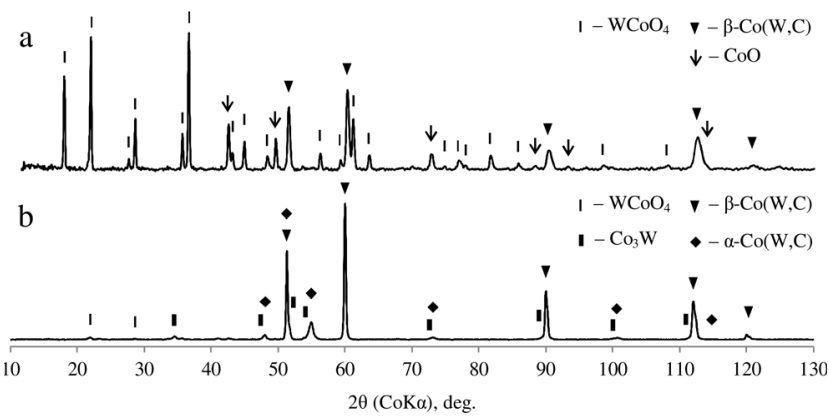

Fig. 6. XRD patterns of sample (1) $25 \% \mathrm{WC}-75 \%$ Co obtained by SLM after annealing: $\mathrm{a}-1 \mathrm{~h}$ at $1300^{\circ} \mathrm{C}$ in air; $\mathrm{b}-1 \mathrm{~h}$ at $1200^{\circ} \mathrm{C}$ in argon.

transformation to $\mathrm{W}_{4} \mathrm{Co}_{2} \mathrm{C}$ carbide as in the sample (1). The sample (1) was heat treated in air $\left(1300{ }^{\circ} \mathrm{C}, 1 \mathrm{~h}\right.$, cooling with furnace) and in argon $\left(1200^{\circ} \mathrm{C}, 1 \mathrm{~h}\right.$, cooling with furnace). XRD patterns of the sample (1) after heat treatment are given in Figure 6. During the heat treatment in air the sample's surface oxidizes strongly and consists mainly of $\mathrm{CoWO}_{4}$ and $\mathrm{CoO}$ oxide phases, also containing a small amount of $\beta-\mathrm{Co}(\mathrm{W}, \mathrm{C})$ with the lattice parameter of $0.356 \mathrm{~nm}$ (Fig. 6a). After heat treatment in argon sample 
(1) contains $\beta-\mathrm{Co}(\mathrm{W}, \mathrm{C})$ with the lattice parameter of $0.357 \mathrm{~nm}, \mathrm{~W}$ and $\mathrm{C}$ solid solution based on hexagonal $\alpha$-Co $(\mathrm{W}, \mathrm{C})$ (lattice parameters $a=0.253 \mathrm{~nm}$ and $c=0.412 \mathrm{~nm}$ ), $\mathrm{Co}_{3} \mathrm{~W}$ phase and traces of $\mathrm{CoWO}_{4}$ oxide (Fig. 6b). The formation of the $\alpha$-Co-based solid solution is testified by the changed lattice parameters as compared to the initial Co powder. The difference in lattice parameters of $\beta$-Co $(\mathrm{W}, \mathrm{C})$ phase in the samples $(1)$ and $(2)$ is attributed to a different amount of $\mathrm{W}$ and $\mathrm{C}$ dissolved in $\beta$-Co. The compositions of samples (1) and (2) in atomic percentage are $\mathrm{W}_{8.4} \mathrm{C}_{8.4} \mathrm{Co}_{83.2}$ and $\mathrm{W}_{9.3} \mathrm{C}_{9.3} \mathrm{Co}_{81.4}$ (Table 1); the sample (2) contains a greater amount of $\mathrm{W}$ and $\mathrm{C}$ and therefore has a greater lattice parameter; moreover, a small amount of $\mathrm{W}_{4} \mathrm{Co}_{2} \mathrm{C}$ phase can be observed in the sample (1), which testifies that $\mathrm{W}$ and $\mathrm{C}$ contained in the sample have not been fully dissolved in $\beta$-Co. Decreasing of $\beta$-Co $(\mathrm{W}, \mathrm{C})$ lattice parameter after heat treatment testifies partial decomposition of the solid solution. It is difficult to say anything of the decomposition because of strong oxidation of the sample (1) surface after heat treatment in air. After heat treatment in argon, $\alpha-\mathrm{Co}$ and $\mathrm{Co}_{3} \mathrm{~W}$ phases are formed as a result of the $\beta-\mathrm{Co}(\mathrm{W}, \mathrm{C})$ decomposition. In general, the formation of the solid solution based on $\beta$-Co high-temperature phase can be explained by stabilization of fcc $\beta$-Co high-temperature modification [22] during the dissolution of tungsten carbide in cobalt; moreover, the cooling process during SLM is of quenching nature. Sample compositions and $\beta-\mathrm{Co}(\mathrm{W}, \mathrm{C})$ lattice parameter in the samples (1) and (2) match the results of work [26] quite well, where fcc $\beta-\mathrm{Co}(\mathrm{W}, \mathrm{C})$ supersaturated solid solution was formed in $\mathrm{Co}-\mathrm{W}-\mathrm{C}$ alloys with a high Co content. The sample (3) contains $\mathrm{W}_{3} \mathrm{Co}_{3} \mathrm{C}$ and $\beta-\mathrm{Co}(\mathrm{W}, \mathrm{C})$ (Fig. $5 \mathrm{c}$ ). The lattice parameter of the $\beta-\mathrm{Co}(\mathrm{W}, \mathrm{C})$ is $0.362 \mathrm{~nm}$, this value corresponds to the composition of $\mathrm{W}_{10} \mathrm{C}_{10} \mathrm{Co}_{80}$ [26]. The chemical composition of the sample (3) is $\mathrm{W}_{18.8} \mathrm{C}_{18.8} \mathrm{Co}_{62.4}$ (Table 1). The WC tungsten carbide not found in the sample partially transformed to $\mathrm{W}_{3} \mathrm{Co}_{3} \mathrm{C}$ carbide and was partially dissolved in $\beta$-Co. The sample (4) contains $\mathrm{WC}$ and $\mathrm{W}_{2} \mathrm{C}$ phases, and $\mathrm{CoO}$ oxide (Fig. $5 \mathrm{~d}$ ). Traces of $\mathrm{CoO}$ oxides in this sample and $\mathrm{CoWO}_{4}$ in other samples (except sample (1) after heat treatment in air) is probably related to surface oxidation during the laser treatment. However, the results of chemical analysis of the sample (4) cross-section also revealed the presence of cobalt at some depth from the surface. The absence of pure cobalt peak points on the XRD pattern of the sample (4) is related to low cobalt content in the sample and low X-ray penetrability. The formation of $\mathrm{W}_{4} \mathrm{Co}_{2} \mathrm{C}, \mathrm{W}_{3} \mathrm{Co}_{3} \mathrm{C}$, and $\mathrm{W}_{2} \mathrm{C}$ carbide phases testifies the decreased carbon amount in the samples, which may be connected with its burningout in the course of materials melting during the SLM laser treatment [22-24]. The peak points in XRD patterns which failed to be identified are marked by "?".

Microstructures of the samples (1)-(4) are given in Figure 7. Microstructures of the samples (1) and (2) do not contain any visible inclusions, which conforms to the information about phase composition and confirms practically full WC dissolution in cobalt (Fig. 7a and b). The sample (1) has a dendritic structure. Diagonal dark and light lines alternating at the distance of $50 \mu \mathrm{m}$ can be
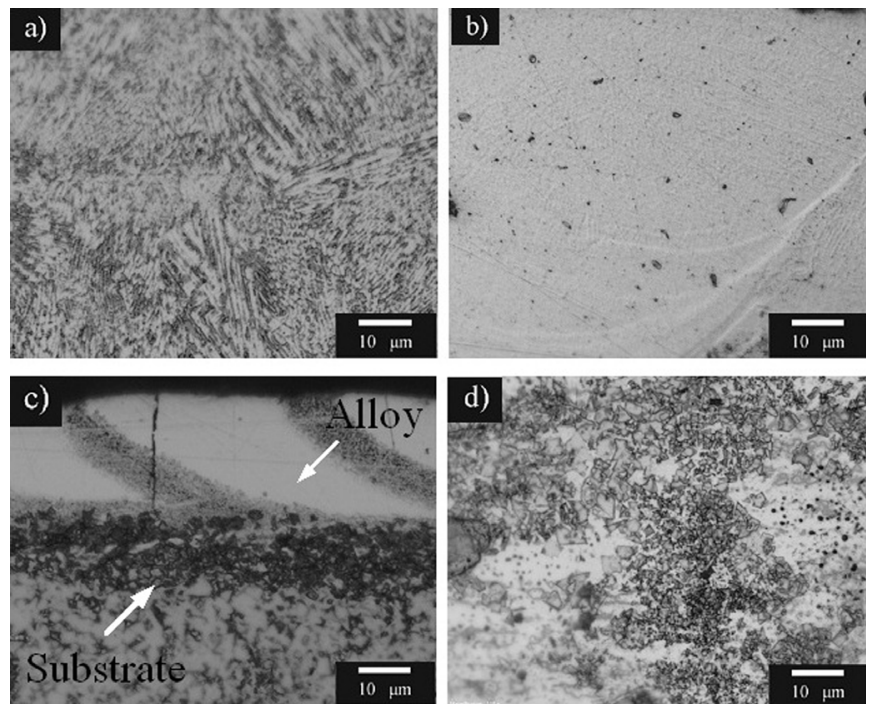

Fig. 7. Microstructure of samples obtained by SLM (crosssection): a - (1) $25 \% \mathrm{WC}-75 \% \mathrm{Co}$; b - (2) 30\% BK8-70\% Co; c (3) $50 \%$ WC-50\% Co; d - (4) $94 \%$ WC-6\% Co.

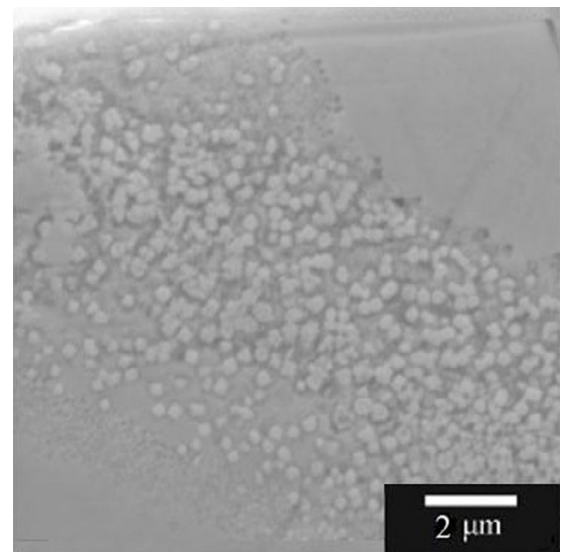

Fig. 8. Microstructure of dark line in sample (3) $50 \%$ WC-50\% Co.

observed on the cross-section of the sample (3). Light lines correspond to $\beta-\mathrm{Co}(\mathrm{W}, \mathrm{C})$ phase. Dark lines contain a lot of submicron inclusions of $\mathrm{W}_{3} \mathrm{Co}_{3} \mathrm{C}$ phase which were released as a result of repeated laser heating during the parallel scanning of the next track in the powder layer (Fig. 8). The distance of $50 \mu \mathrm{m}$ between the lines of the outlined carbide phase corresponds to the scanning step of $50 \mu \mathrm{m}$. The sample (4) (Fig. 7d) contains equally distributed over the whole volume micron and submicron fractions of $\mathrm{WC}$ and $\mathrm{W}_{2} \mathrm{C}$ carbide phases in the cobalt matrix.

\section{Conclusions}

This work has studied the microstructure and phase composition of WC-Co alloys obtained by SLM. To obtain bulk alloys, initial powder mixtures containing 25, 27.6, 50, and $94 \mathrm{wt} . \% \mathrm{WC}$ as well as $75,72.4,50$, and $6 \mathrm{wt.} \% \mathrm{Co}$ accordingly were used. During the SLM in alloys with 75 
and 72.4 wt.\% Co, WC phase dissolves completely with the formation of the face-centered cubic $\beta$-Co-based solid solution $\beta-\mathrm{Co}(\mathrm{W}, \mathrm{C})$ containing $\mathrm{W}$ and $\mathrm{C}$. A small amount of $\mathrm{W}_{4} \mathrm{Co}_{2} \mathrm{C}\left(\mathrm{Me}_{6} \mathrm{C}\right)$ carbide is formed in the alloy with 75 wt.\% Co. WC carbide is completely dissolved in the alloy with 50 wt. $\%$ Co transforming to $\mathrm{W}_{3} \mathrm{Co}_{3} \mathrm{C}\left(\mathrm{Me}_{6} \mathrm{C}\right)$ carbide and forming $\beta-\mathrm{Co}(\mathrm{W}, \mathrm{C})$ phase. $\mathrm{WC}$ carbide is retained in alloy with 6 wt. $\% \mathrm{Co}$, and $\mathrm{W}_{2} \mathrm{C}$ carbide is formed. The $\beta$-Co lattice parameter in initial powder and lattice parameter of $\beta-\mathrm{Co}(\mathrm{W}, \mathrm{C})$ in alloys with $75,72.4$, and $50 \mathrm{wt} . \%$ Co are $0.354,0.360,0.361$, and $0.362 \mathrm{~nm}$, accordingly. During annealing of the alloy with $75 \mathrm{wt} . \% \mathrm{Co}, \beta-\mathrm{Co}(\mathrm{W}, \mathrm{C})$ solid solution partly decomposes forming $\mathrm{Co}_{3} \mathrm{~W}$ phase and hexagonal $\alpha$-Co-based solid solution. The formation of $\mathrm{W}_{4} \mathrm{Co}_{2} \mathrm{C}, \mathrm{W}_{3} \mathrm{Co}_{3} \mathrm{C}$, and $\mathrm{W}_{2} \mathrm{C}$ carbides occurs due to decreasing carbon content in alloys. No inclusions are observed in the microstructure of alloys with 75 and 72.4 wt. $\%$ Co. $\mathrm{Co}_{3} \mathrm{~W}_{3} \mathrm{C}, \mathrm{WC}$, and $\mathrm{W}_{2} \mathrm{C}$ carbide phases in the cobalt matrix are seen in the microstructure of alloys with 50 and 6 wt.\% Co. The obtained results can be used in the metalworking industry and materials science for production of hard alloys and products from it both by traditional sintering and by additive manufacturing methods.

Acknowledgements. This work was financially supported by the Ministry of Education and Science of Russian Federation in the framework of the state No.11.1267.2017/4.6. The work is carried out on the equipment of the Center of collective use of MSTU "STANKIN".

\section{References}

[1] D. Herzog, V. Seyda, E. Wycisk, C. Emmelmann, Additive manufacturing of metals, Acta Materialia 117 (2016) 371392

[2] E.O. Olakanmi, R.F. Cochrane, K.W. Dalgarno, A review on selective laser sintering/melting (SLS/SLM) of aluminum alloy powders: processing, microstructure, and properties, Prog. Mater. Sci. 74 (2015) 401-477

[3] I. Smurov, M. Doubenskaia, S. Grigoriev, A. Nazarov, Optical Monitoring in Laser Cladding of Ti6Al4V, J. Thermal Spray Technol. 21 (2012) 1357-1362

[4] B. Vayre, F. Vignat, F. Villeneuve, Metallic additive manufacturing: state-of-the-art review and prospects, Mechanics \& Industry 13 (2012) 89-96

[5] T.V. Tarasova, A.P. Nazarov, M.V. Prokof'ev, Effect of the regimes of selective laser melting on the structure and physicomechanical properties of cobalt-base superalloys, Phys. Metals Metall. 116 (2015) 601-605

[6] S.N. Grigoriev, T.V. Tarasova, Possibilities of the technology of additive production for making complex-shape parts and depositing functional coatings from metallic powders, Metal Sci. Heat Treatment 57 (2016) 579-584

[7] D.Q. Zhang, Z.H. Liu, Q.Z. Cai, J.H. Liu, C.K. Chua, Influence of $\mathrm{Ni}$ content on microstructure of $\mathrm{W}-\mathrm{Ni}$ alloy produced by selective laser melting, Int. J. Refract. Metals Hard Mater. 45 (2014) 15-22
[8] E. Uhlmann, A. Bergmann, W. Gridin, Investigation on additive manufacturing of tungsten carbide-cobalt by selective laser melting, Procedia CIRP 35 (2015) 8-15

[9] X.C. Wang, T. Laoui, J. Bonse, J.P. Kruth, B. Lauwers, L. Froyen, Direct selective laser sintering of hard metal powders: experimental study and simulation, Int. J. Adv. Manuf. Technol. 19 (2002) 351-357

[10] S.N. Grigoriev, A.A. Vereshchaka, Methodology of formation of multi-layered coatings for carbide cutting tools, Mechanics \& Industry 17 (2016) 706

[11] A.A. Vereschaka, A.S. Vereschaka, A.D.L. Batako, B.J. Mokritskii, A.Y. Aksenenko, N.N. Sitnikov, Improvement of structure and quality of nanoscale multilayered composite coatings, deposited by filtered cathodic vacuum arc deposition method, Nanomater. Nanotechnol. 7 (2017) 13

[12] A.A. Vereschaka, B.Y. Mokritskii, N.N. Sitnikov, G.V. Oganyan, A.Y. Aksenenko, Study of mechanism of failure and wear of multi-layered composite nano-structured coating based on system Ti-TiN-(ZrNbTi)N deposited on carbide substrates, J. Nano Res. 45 (2017) 110-123

[13] A.A. Vereschaka, J. Prilukova, A.S. Vereshchaka, J. Bublikov, A. Aksenenko, Control of temperature in cutting zone in machining of alloyed case-hardened steels by applying a ceramic tool with wear-resistant coatings, Mater. Sci. Forum 857 (2016) 199-205

[14] H. Abdel-Aal, M. El Mansori, Wear of WC-Co inserts in dry high-speed machining of micron-sized particle aeronautical grade near $\beta$ titanium alloy, Mechanics \& Industry 15 (2014) 413-426

[15] Yu.V. Lakhotkin, V.V. Dushik, V.P. Kuz'min, N.V. Rozhanskii, Nanostructured hard coatings: the key to safe operation of equipment in extreme conditions, Prot. Metals Phys. Chem. Surf. 7 (2015) 1165-1169

[16] V.V. Dushik, Yu.V. Lakhotkin, V.P. Kuzmin, N.V. Rozhanskii, The corrosion behavior of hard $\mathrm{W}-\mathrm{C}$ system chemical vapor deposition layers in $\mathrm{HCl}$ and $\mathrm{H} 2 \mathrm{~S}$ aqueous solutions, Prot. Metals Phys. Chem. Surf. 7 (2016) 1153-1156

[17] T. Laoui, L. Froyen, J.P. Kruth, Effect of mechanical alloying on selective laser sintering of WC-9Co powder, Powder Metall. 42 (1999) 203-205

[18] R.S. Khmyrov, V.A. Safronov, A.V. Gusarov, Obtaining crack-free WC-Co alloys by selective laser melting, Phys. Procedia 83 (2016) 874-881

[19] R.S. Khmyrov, V.A. Safronov, A.V. Gusarov, Synthesis of nanostructured $\mathrm{WC}-\mathrm{Co}$ hardmetal by selective laser melting, Mater. Sci. Forum 834 (2015) 77-83

[20] A.S. Kurlov, A.A. Rempel, Effect of sintering temperature on the phase composition and microhardness of $\mathrm{WC}-8 \mathrm{wt}$ \% Co cemented carbide, Inorg. Mater. 43 (2007) 602-607

[21] N. Al-Aqeeli, N. Saheb, T. Laoui, K. Mohammad, The synthesis of nanostructured WC-based hardmetals using mechanical alloying and their direct consolidation, J. Nanomater. 2014 (2014) 640750

[22] A. Bondar, N. Bochvar, T. Dobatkina, N. Krendelsberg, Carbon-Cobalt-Tungsteen: datasheet from Landolt-Bornstein group IV physical chemistry volume 11E2: "Refractory metal systems" in Springer Materials, Springer-Verlag Berlin Heidelberg, Berlin, 2005

[23] T. Johansson, B. Uhrenius, Phase equilibria, isothermal reactions, and a thermodynamic study in the $\mathrm{Co}-\mathrm{W}-\mathrm{C}$ system at $1150^{\circ} \mathrm{C}$, Met. Sci. 12 (1978) 83-94 
[24] E. Lugscheider, H. Reimann, R. Pankert, ๆ-Carbides in CoW-C and Fe-W-C alloys, Z. Metallkd. 73 (1982) 321-324

[25] V.Z. Kublii, T. Ya. Velikanova, Ordering in the Carbide $\mathrm{W}_{2} \mathrm{C}$ and phase equilibria in the tungsten carbon system in the region of its existence, Powder Metall. Metal Ceram. 43 (2004) 630-644 (translated from Poroshk. Metall. 11/12 (2004) 101-116

[26] A. Inoue, Y. Harakawa, T. Masumoto, Nonequilibrium phase in melt-quenched $\mathrm{Co}-\mathrm{W}-\mathrm{C}$ alloys and their powder-forming tendency by comminution, Sci. Rep. Res. Inst. Tohoku Univ. A32 (1985) 297-308
[27] E.V. Shelekhov, T.A. Sviridova, Programs for X-ray analysis of polycrystals, Metal Sci. Heat Treat. 42 (2000) 309-313

[28] S. Grazulis, D. Chateigner, R.T. Downs, A.T. Yokochi, M. Quiros, L. Lutterotti, E. Manakova, J. Butkus, P. Moeck, A. Le Bail, Crystallography open database - an open-access collection of crystal structures, J. Appl. Cryst. 42 (2009) 726729

Cite this article as: R.S. Khmyrov, A.P. Shevchukov, A.V. Gusarov, T.V. Tarasova, Phase composition and microstructure of WC-Co alloys obtained by selective laser melting, Mechanics \& Industry 18, 714 (2017) 